Ryszard BARTEL

\title{
EFFECTIVENESS OF STOCKING TAGGED RAINBOW TROUT (SALMO GAIRDNERI RICH.) INTO THE BALTIC SEA
}

\section{EFEKTYWNOŚĆ ZARYBIANIA BALTYKU PSTRĄGAMI TĘCZOWYMI (SALMO GAIRDNERI RICH.)}

\author{
Inland Fisheries Institute, Olsztyn \\ Laboratory of River Fisheries, Gdańsk-Oliwa
}

\begin{abstract}
From among 40505 tagged rainbow trout, released at the age of $0+, 1$ and 2 years into the Baltic Sea, the Vistula River and some Pomeranian rivers, 0.0 to $14.7 \%$ of the tags were returned during the first $3-4$ months after the release, and 0.1 to $20.9 \%$ later on. Effectiveness of stocking was calculated as $\mathrm{kg}$ of the catch per each 1000 released trouts. It varied from 0.4 to $418 \mathrm{~kg}$ and depended on the time and place of release, fish age and size, growth rate, and intensity of exploitation. Share of Polish fishermen in rainbow trout catches varied from 30.8 to $100 \%$ and depended mostly on the place of fish release.
\end{abstract}

\section{INTRODUCTION}

Deteriorating spawning and feeding conditions for sea trout in the rivers made it necessary to maintain the diminishing populations of this species by continuous artificial stocking with smolts of lower river courses and the sea. At the same time, attempts were made to introduce rainbow trout into the Baltic Sea (Meyer 1939, Kulmatycki 1940, Inst. Küsten u. Binnenfisch. 1970. Bartel 1973, Trzebiatowski 1979). Per cents of tag returns were very high in some experiments (Bartel 1985 in print). This suggested that the measure can be of interest to salmonid fishery. The aim of the present work was to determine the effectiveness of rainbow trout stocking into the Baltic Sea, to determine 
factors affecting this effectiveness, and to find out what countries participated in the catches of tagged rainbow trout.

\section{MATERIAL AND METHOD}

Totally 40505 tagged rainbow trouts were released in the period 1963-1980. The fishes were at the age of $0+, 1$ and 2 years, of body length (long. caud.) $11-49 \mathrm{~cm}$. They were released most of all into the Gulf of Gdańsk near Gdańsk, near Jastarnia, toward the open sea, and into the Vistula mouth at Swibno. Some trouts were also released into the rivers: Reda, Słupia, Wieprza, into the Puck Bay, the Vistula Firth, and into the Baltic Sea at Mielno (Tab. 1, Fig. 1).

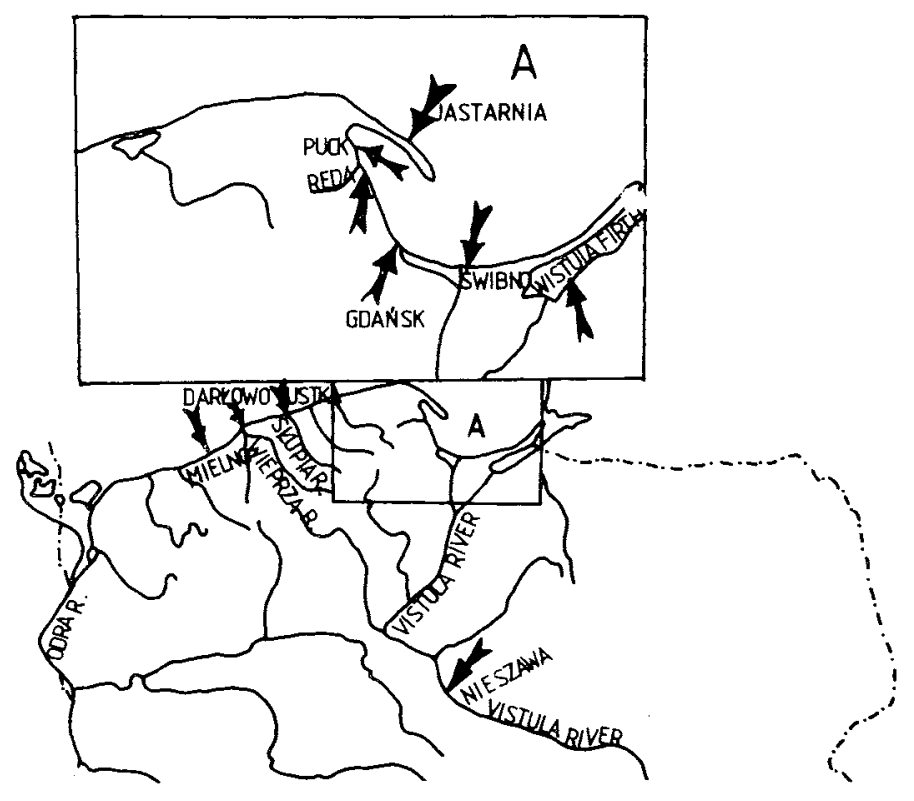

Fig. 1 - Sites of releasing tagged rainbow trout (see arrows)

Fish weight was calculated taking advantage of the equation given by Sych et al. (1980), worked out on the basis of measurements material of rainbow trout reared in Poland. The equation is:

$$
\mathrm{W}=0.008585 \times \mathrm{L}^{3,084237}
$$

where: $\quad \mathrm{L}-$ total fish length in $\mathrm{cm}$,

$\mathrm{W}-$ fish weight in $\mathrm{g}$. 
Average weight of rainbow trout was calculated taking into account fish size distribution in each experiment, and weight of the fishes was calculated for each $1 \mathrm{~cm}$ length class.

Trouts were tagged with silver or celluloid tags, oval or rectangular, $15 \times 5 \mathrm{~mm}$, attached with silver or monel wire under the dorsal fin, in its front part, between the third and the second basal ray (Bartel 1975a, 1985a).

Effectiveness of stocking was assessed as $\mathrm{kg}$ of trout caught per 1000 released fishes, and as a ratio between mass of the released fishes and catch mass, expressed in per cents. Only returns from "older" fishes were used in the calculations, i.e. those caught after July of the first year of sea life. No consideration was given to earlier catches of "younger" fishes as they had no significant effect on the catch mass due to negligible body weight increments. On the contrary, it can be even stated that the latter returns decreased number of the released fishes, and thus lowered the final effect.

\section{RESULTS}

Effectiveness of stocking.

Mass of caught trout per 1000 released fishes was used as a measure of the effectiveness of stocking together with the ratio between this mass and catch weight (Tab. 1). The final effect depended most of all on the season and place of fish release. The lowest effectiveness was observed in case of autumn fry released into the Gulf of Gdańsk. Only $2.5 \mathrm{~kg}$ were caught per 1000 released fishes of total weight of $36.5 \mathrm{~kg}$, this being as little as $6.8 \%$ in relation to the weight of stocking (Tab. 1). Better results were obtained in case of spring release of one-year old rainbow trout into the Gulf of Gdańsk at Gdańsk and Jastarnia, and into the Vistula mouth. They amounted on the average to $126.1 \mathrm{~kg}$ (Gdańsk) and $134.3 \mathrm{~kg}$ (Świbno), ranging from 65.3 to $433.9 \%$ in relation to total weight of the released fishes (Tab. 1). On the other hand, returns for trout released in spring into the Vistula at Nieszawa, into the Vistula Firth, Baltic Sea and Mielno, and mouth of the rivers Słupia and Wieprza were very low, so that the effectiveness amountet to $0.4-17.9 \mathrm{~kg} / 1000$ released fishes. In each case the catch was lower than stocking (Tab. 1). Similar trends were observed in case of spring release of two-year old fishes. Fishes released at Gdańsk gave ồetter results than those from Reda and Puck Bay. In the two latter places weight of trout catch was always lower than the stocking (Tab. 1).

Generally, better results were obtained with two-years old fishes. It should be noticed that these fishes were not only older but also bigger, so that their survival was probably higher. However, effects of these stockings measured in the ratio between weight of catch and stocking were slightly lower than in case of one-year old trout (Tab. 1).

Per cent of returns noticably affected the effectiveness of stocking. This was observed both for one- and two-years old fishes. Correlation coefficients calculated for the dependence between per cent of returned tags from "older" fishes ( $\mathrm{x}$ ) and $\mathrm{kg}$ of trout 
Economic effects of stocking with rainbow trout

\begin{tabular}{|c|c|c|c|c|c|c|}
\hline \multirow{2}{*}{$\begin{array}{l}\text { No of }{ }^{3} \\
\text { expe- } \\
\text { riments }\end{array}$} & \multicolumn{6}{|c|}{ Released } \\
\hline & & Date, Place & Age & $\begin{array}{l}\text { Average } \\
\text { length } \\
\mathrm{cm}\end{array}$ & $\begin{array}{l}\text { Average } \\
\text { weigth } \\
\text { g }\end{array}$ & $\begin{array}{c}\text { Number } \\
\text { of } \\
\text { individ. }\end{array}$ \\
\hline 1 & 4.11 .63 & Gulf of Gdańsk, Gdańsk & $0+$ & 14.9 & 36.5 & 1804 \\
\hline 2 & 14.05 .64 & Gulf od Gdańsk, Gdańsk & 1 & 16.9 & 53.6 & 658 \\
\hline 3 & 19.05 .66 & Gulf od Gdańsk, Gdańsk & 1 & 18.3 & 68.4 & 1348 \\
\hline 4 & 13.05 .67 & Gulf of Gdarisk, Gdańsk & 1 & 23.5 & 148.8 & 1544 \\
\hline 5 & 6.05 .68 & Gulf of Gdańsk, Gdańsk & 1 & 16.0 & 45.7 & 969 \\
\hline 6 & $10-11.06 .68$ & Gulf of Gdańsk, Gdańsk & 1 & 15.5 & 40.3 & 868 \\
\hline 7 & 28.05 .69 & Gulf of Gdańsk, Gdańsk & 1 & 16.7 & 52.4 & 468 \\
\hline 8 & 22.04 .72 & Gulf of Gdańsk, Gdańsk & 1 & 16.8 & $54.5^{\circ}$ & 1322 \\
\hline 9 & $23-24.06 .72$ & Gulf of Gdańsk, Gdańsk & 1 & 16.7 & 52.9 & 2394 \\
\hline Total & & Gulf of Gdańsk & 1 & 17.9 & 69.0 & 9571 \\
\hline 10 & $5-13.05 .67$ & Gulf of Gdańsk, Gdańsk & 2 & 28.0 & 275.3 & 1124 \\
\hline 11 & 30.04 .68 & Gulf of Gdańsk, Gdańsk & 2 & 22.3 & 141.8 & 672 \\
\hline 12 & $8-9.05 .69$ & Gulf of Gdańsk, Gdańsk & 2 & 22.3 & 129.6 & 1515 \\
\hline 13 & 13.04 .70 & Gulf of Gdańsk, Gdańsk & 2 & 21.3 & 113.3 & 1599 \\
\hline 14 & 13.04 .71 & Gulf od Gdańsk, Gdańsk & 2 & 22.3 & 132.7 & 876 \\
\hline 15 & 18.03 .72 & Gulf of Gdańsk, Gdańsk & 2 & 23.0 & 139.2 & 769 \\
\hline 16 & 30.03 .72 & Gulf of Gdańsk, Gdańsk & 2 & 25.4 & 196.6 & 201 \\
\hline Total: & & Gulf of Gdańsk, Gdańsk & 2 & 23.2 & 154.7 & 6756 \\
\hline 17 & 19.05 .65 & Vistula mouth, Świbno & 1 & 18.7 & 75.5 & 846 \\
\hline 18 & $20.05-1.06 .66$ & Vistula mouth, Świbno & 1 & 18.4 & 75.9 & 3099 \\
\hline 19 & 18.05 .67 & Vistula mouth, Swibno & 1 & 20.0 & 92.9 & 1198 \\
\hline 20 & 10.05 .68 & Vistula mouth, Świbno & 1 & 16.1 & 46.3 & 990 \\
\hline Total: & & Vistula mouth, Świbno & 1 & 18.4 & 74.4 & 6133 \\
\hline 21 & 2.06 .66 & Gulf of Gdańsk, Jastamia & 1 & 18.5 & 70.5 & 1164 \\
\hline 22 & 28.05 .67 & Vistula Firth, Suchacz & 1 & 18.5 & 71.6 & 1338 \\
\hline 23 & 9.05 .68 & Vistula Firth, Suchacz & 1 & 15.8 & 43.6 & 822 \\
\hline 24 & 20.04 .68 & Vistula River, Nieszawa & 1 & 17.0 & 54.5 & 1348 \\
\hline 25 & $4-\quad 5.05 .70$ & Vistula River, Nieszawa & 1 & 15.5 & 41.9 & 825 \\
\hline 27 & $16-20.05 .68$ & Reda River, Mrzezino & 2 & 24.8 & 177.8 & 237 \\
\hline 28 & 17.05 .68 & Puck Bay, Puck & 2 & 23.2 & 142.5 & 100 \\
\hline 29 & 17.05 .68 & Baltic Sea, Mielno & 1 & 16.3 & 50.0 & 621 \\
\hline 36 & 6.05 .78 & Wieprza River, Darłowo & 1 & 19.6 & 87.2 & 1992 \\
\hline 37 & 10.05 .78 & Wieprza River, Darłowo & 1 & 19.6 & 85.6 & 1999 \\
\hline 38 & 24.04 .79 & Słupia River, Ustka & 1 & 16.9 & 55.7 & 1798 \\
\hline 39 & 30.05 .80 & Słupia River, Ustka & 1 & 18.1 & 69.0 & 3997 \\
\hline Total: & & & & & & 40505 \\
\hline
\end{tabular}

${ }^{1}$ fish caught till the end of July of the year of release

${ }^{2}$ fish caught later than in July of the year of release

${ }^{3}$ number of experiments and their detail data are presented in the paper by Bartel (1985a) 


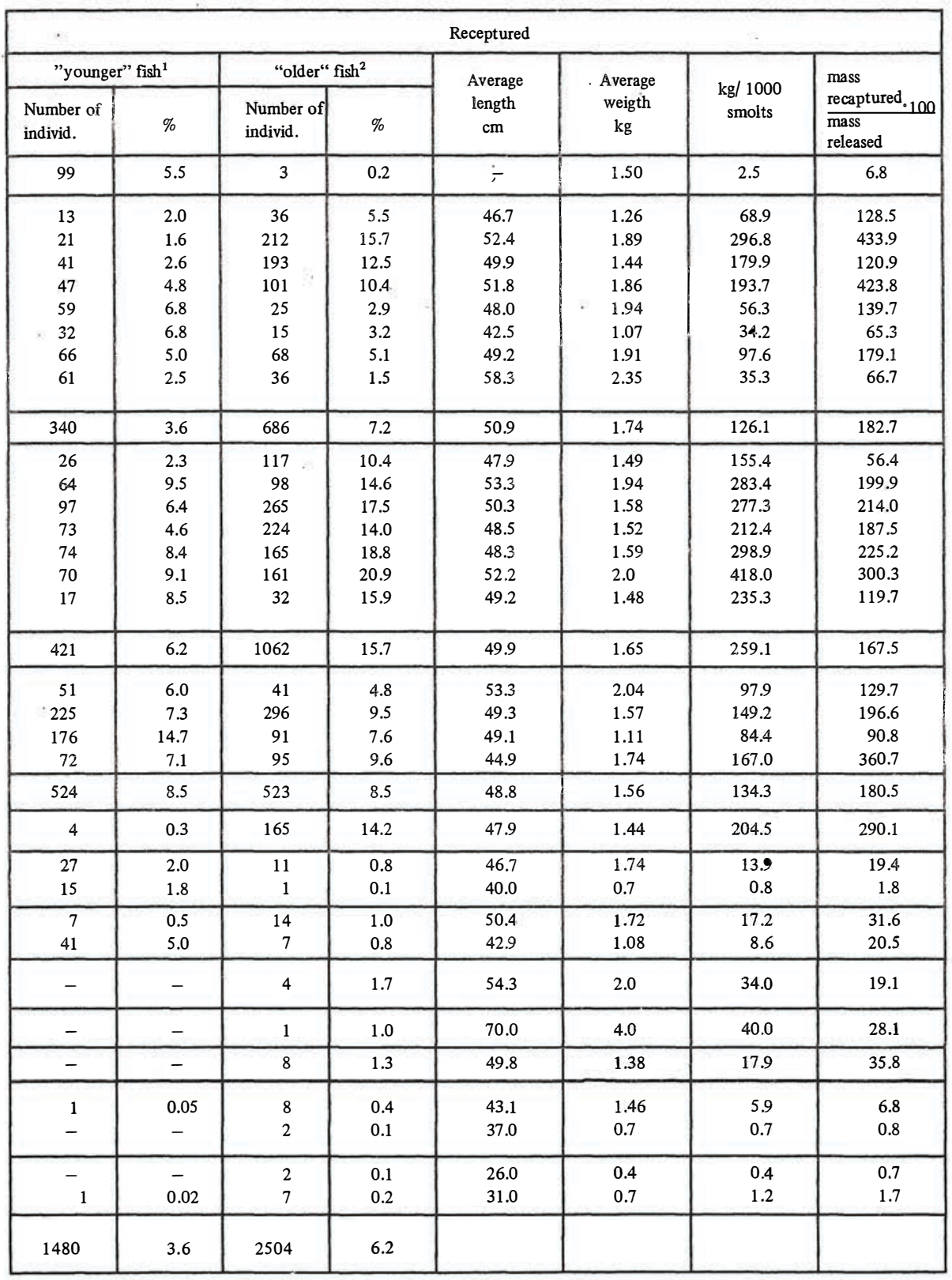


catch per 1000 released $(W)$ were highly significant, reaching the values of $r_{1}=0.971$ and $\mathrm{r}_{2}=0.963$. The calculated equations of linear regression are:

for one-year old fishes:

$$
\mathrm{W}_{1}=16.5814 \mathrm{x}-3.6106
$$

for two-years old fishes:

$$
\mathrm{W}_{2}=16.843 \mathrm{x}+2.3346 \text {. }
$$

The lines are almost parallel (Fig. 2).

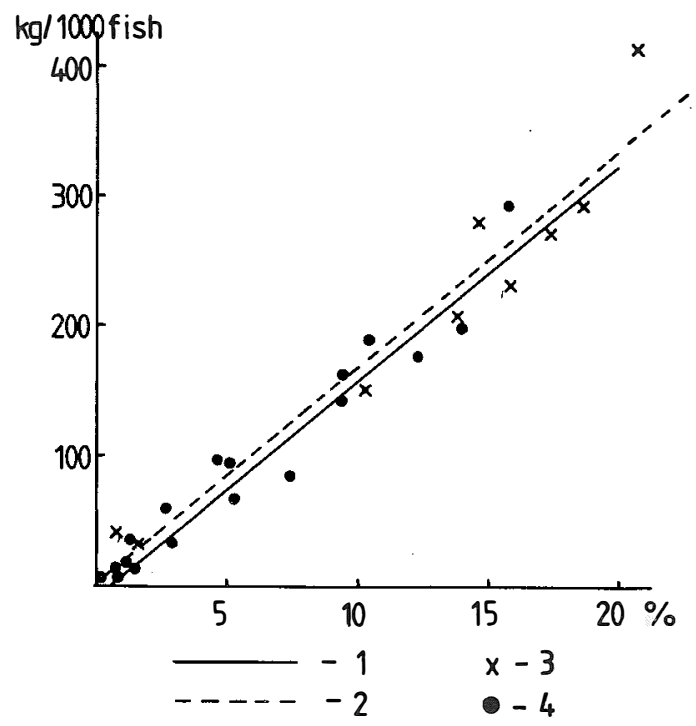

Fig. 2. Relation between $\mathrm{kg}$ of fish caught per 1000 fish released and the per cent of returns of "older" rainbow trout: 1 - for one-year old rainbow trout released; regression equation $\mathrm{W}_{1}=16,581 \mathrm{x}-3,6106,2-$ for two-years old rainbow trout released; regression equation $\mathrm{W}_{2}=16.843 \mathrm{x}-2,3346,3-\mathrm{kg}$ of fish caught per 1000 rainbow trout released at the age of one year in particular experiments, $4-\mathrm{kf}$ of fish caught per 1000 rainbow trout released at the age of two years in particular experiments.

Effectiveness of stocking was also affected by the rate of fish catches. Too early exploitation after the fish release resulted in lower average weight of the caught fishes. On the average, trouts originating from the releases of one-year old fishes were heavier than those originating from the introductions of two-years old fishes (Tab. 1), although growth of the latter was better in successive years after the release. This was caused by the fact that frequency of trout catches was much higher in the first year after the release in case of older stocking material (73.3\%) compared to younger (43.6\%, Tab. 2). Average weight of "older" fishes in the experiments with two-years old rainbow trout ranged between 1.43 and $2.0 \mathrm{~kg}$. In case of one-year old trout these variations were much higher: from 1.07 to $2.35 \mathrm{~kg}$. This was caused by the differences in per cent of returns of "older" fishes in the first year after stocking, which ranged between 20.0 and $73.3 \%$ for trout 
Percentage of "older" rainbow trout caught in consecutive years after release, annual periods from April to March

\begin{tabular}{|c|c|c|c|c|c|c|c|c|}
\hline \multirow{4}{*}{$\begin{array}{l}\text { No } \\
\text { experi- } \\
\text { ment }\end{array}$} & \multicolumn{3}{|c|}{ Released } & \multicolumn{5}{|c|}{ Receptured (grand total) } \\
\hline & \multirow{3}{*}{ Place } & \multirow{3}{*}{ Year } & \multirow{3}{*}{$\begin{array}{l}\text { Age } \\
\text { of } \\
\text { fish }\end{array}$} & \multicolumn{3}{|c|}{ Years after release } & \multirow{3}{*}{$\begin{array}{c}\text { Total } \\
\text { number } \\
\text { of } \\
\text { indiv. }\end{array}$} & \multirow{3}{*}{$\begin{array}{l}\text { Average } \\
\text { weight } \\
\text { of fish } \\
\text { in kg. }\end{array}$} \\
\hline & & & & 1 & 2 & 3 & & \\
\hline & & & & $\%$ & $\%$ & $\%$ & & \\
\hline 2 & Gdańsk & 1964 & 1 & 50.0 & 94.9 & 97.2 & 36 & 1.26 \\
\hline 3 & Gd ańsk & 1966 & 1 & 35.4 & 85.8 & 97.2 & 212 & 1.89 \\
\hline 4 & Gdańsk & 1967 & 1 & 56.5 & 89.1 & 97.4 & 193 & 1.44 \\
\hline 5 & Gdańsk & 1968 & 1 & 38.6 & 90.1 & 97.0 & 101 & 1.86 \\
\hline 6 & Gdańsk & 1968 & 1 & 20.0 & 84.0 & 92.0 & 25 & 1.94 \\
\hline 7 & Gdańsk & 1969 & 1 & 73.3 & 86.7 & 93.3 & 15 & 1.07 \\
\hline 8 & Gdańsk & 1972 & 1 & 64.7 & 98.5 & 100.0 & 68 & 1.91 \\
\hline 9 & Gdańsk & 1972 & 1 & 30.6 & 86.1 & 94.4 & 36 & 2.35 \\
\hline 17 & Świbno & 1965 & 1 & 21.9 & 61.0 & 92.7 & 41 & 2.04 \\
\hline 18 & Świbno & 1966 & 1 & 42.2 & 89.2 & 95.9 & 296 & 1.57 \\
\hline 19 & Świbno & 1967 & 1 & 65.9 & 90.1 & 96.7 & 91 & 1.11 \\
\hline 20 & Świbno & 1968 & 1 & 32.6 & 82.1 & 88.4 & 95 & 1.74 \\
\hline 21 & Jastarnia & 1966 & 1 & 37.6 & 93.3 & 98.8 & 165 & 1.44 \\
\hline \multicolumn{3}{|c|}{ Average: } & 1 & 43.6 & 88.4 & 95.6 & 1374 & 1.63 \\
\hline 10 & Gdańsk & 1967 & 2 & 56,4 & 95,7 & 99,1 & 117 & 1.43 \\
\hline 11 & Gdańsk & 1968 & 2 & 66.3 & 95.9 & 96.9 & 98 & 1.94 \\
\hline 12 & Gdańsk & 1969 & 2 & 75.5 & 95.1 & 98.9 & 265 & 1.58 \\
\hline 13 & Gdańsk & 1970 & 2 & 75.9 & 96.0 & 99.1 & 224 & 1.52 \\
\hline 14 & Gdańsk & 1971 & 2 & 80.0 & 95.8 & 96.4 & 164 & 1.59 \\
\hline 15 & Gdańsk & 1972 & 2 & 73.9 & 95.0 & 95.7 & 161 & 2.00 \\
\hline 16 & Gdańsk & 1972 & 2 & 81.3 & 100.0 & & 32 & 1.48 \\
\hline \multicolumn{3}{|c|}{ Average: } & 2 & 73.3 & 95.7 & 97.9 & 1062 & 1.65 \\
\hline
\end{tabular}

stocked at the age of one year, and between 56.4 and $81.3 \%$ for trout stocked at the age of two years (Tab. 2). Correlation between per cent of returned older fishes in the first year $\left(\mathrm{x}_{1}\right)$ and average weight of older fishes $(\mathrm{W})$ in particular experiments amounted to $r_{1}=-0.714$ and was highly significant (confidence level of 0.01 at 11 degrees of freedom). Regression equation calculated for this dependence is (Fig. 3):

$$
\mathrm{W}_{1}=0.0161 \mathrm{x}_{1}+\mathrm{W} 2.368
$$

The same dependence for two-years old trout amounted to $r_{2}=-0.0312$ and was not significant statistically. 


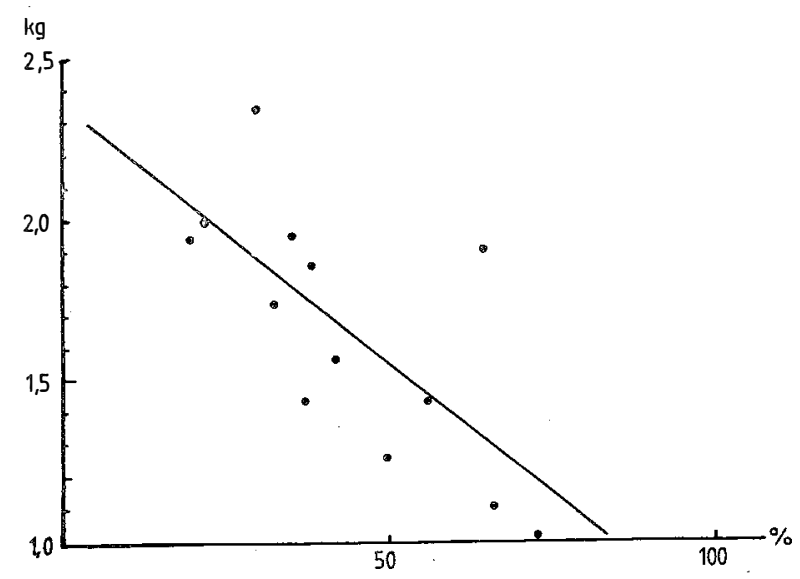

Fig. 3. Relation between per cent of rainbow trout caught during the first year after the release $\left(\mathrm{x}_{1}\right)$ and average weight of "older" fish caught (W) in particular experiments. Fishes stocked at the age of one year.

Calculated according to the regression equation: $\mathrm{W}=-0,0161 \mathrm{x}_{1}+2,368$.

Catches of tagged fishes by fishermen from different countries.

Share of fishermen from different countries in the catches of tagged rainbow trout was connected with the fish distribution. Most tagged rainbow trouts were caught by Polish fishermen who supplied 1735 tags out of the total 2504 returns of "older" fishes, i.e. 69.4\%. Rainbow trout was also caught by the fishermen from Denmark, Sweden, German Democratic Republic, Federal Republic of Germany, Soviet Union, Finland and Norway (Tab. 3). Share of these fishermen in the returns varied for particular experiments in different years. Considerable differences were observed depending on the site of release. Polish fishermen caught most fishes (77.0\% of the returns) released to the Vistula mouth at Świbno (from 68.3 to $89.0 \%$ in particular experiments). Returns from Polish fishermen were lower for the fishes released into the Gulf of Gdańsk at Gdańsk (70.7 and 67.9\%), still less for the introductions at Jastamia (45.5\%, Tab. 3).

Danish fishermen caught most fishes released at Jastarnia $(22.4 \%$, less from the releases of two- and one-year old fishes in the Gulf of Gdańsk at Gdańsk(19.7\% and 17.1\%) and in the Vistula mouth at Swibno (11.8.8\%). Swedish fishermen caught $14.5 \%$ of the returned fishes from Jastarnia releases, and 5.4 and $4.0 \%$ from the releases at Gdańsk of one- and two-years old fishes. Similar patterns were observed for the fishermen from GDR and FRG (Tab. 3).

Returns of the fishes released into the Pomeranian rivers (Słupia, Wieprza, Grabowa) Baltic Sea at Mielno, Vistula Firth and Vistula River at Nieszawa were low (12-21\%) so it is difficult to discuss their distribution among the countries (Tab. 3). On top of this, some returns originated from the release sites, and from the summer of the first year (for instance trout released to Słupia and Wieprza), i.e. they were the fishes which remained at the release site. 
Share of particular countries in the catches of tagged rainbow trout

(fish caught from August after the release)

\begin{tabular}{|c|c|c|c|c|c|c|c|c|c|c|c|c|c|}
\hline \multicolumn{5}{|c|}{ Released } & \multicolumn{9}{|c|}{ Caught } \\
\hline \multirow{2}{*}{ Place } & \multicolumn{2}{|c|}{ Experiments } & \multirow{2}{*}{ Age } & \multirow{2}{*}{$\%$} & \multirow{2}{*}{ Poland } & \multirow{2}{*}{ Sweden } & \multirow{2}{*}{ Denmark } & \multirow{2}{*}{ FRG } & \multirow{2}{*}{ GDR } & \multirow{2}{*}{ Finland } & \multirow{2}{*}{ USSR } & \multirow{2}{*}{ Norvay } & \multirow{2}{*}{$\begin{array}{l}\text { Total } \\
\text { indiv. }\end{array}$} \\
\hline & No & Number & & & & & & & & & & & \\
\hline Jastarnia & 21 & 1 & 1 & average & 45.5 & 14.5 & 22.4 & 4.9 & 10.3 & - & 2.4 & - & 165 \\
\hline Świbno & $17-20$ & 4 & 1 & $\begin{array}{l}\text { average } \\
\text { range }\end{array}$ & $\begin{array}{c}77.0 \\
68.3-89.0\end{array}$ & $\begin{array}{c}4.4 \\
3.3-9.8\end{array}$ & $\begin{array}{c}11.8 \\
2.2-24.2\end{array}$ & $\begin{array}{r}3.1 \\
0-4.9\end{array}$ & $\begin{array}{c}1.9 \\
0-2.4\end{array}$ & $\begin{array}{c}0.4 \\
0-2.4\end{array}$ & $\begin{array}{c}1.0 \\
0-7.3\end{array}$ & $\begin{array}{c}0.4 \\
0-0.7\end{array}$ & 523 \\
\hline Gdańsk & $2-9$ & 8 & 1 & $\begin{array}{l}\text { average } \\
\text { range }\end{array}$ & $\begin{array}{c}67.9 \\
48.0-100.0\end{array}$ & $\begin{array}{c}5.4 \\
0-11.8\end{array}$ & $\begin{array}{c}17.1 \\
0-32.0\end{array}$ & $\begin{array}{r}2.9 \\
0-5.6\end{array}$ & $\begin{array}{c}5.8 \\
0-5.6\end{array}$ & $\begin{array}{l}- \\
-\end{array}$ & $\begin{array}{c}0.7 \\
0-2.8\end{array}$ & $\begin{array}{c}0.2 \\
0-0.5\end{array}$ & 686 \\
\hline Gdańsk & $10-16$ & 7 & 2 & $\begin{array}{l}\text { average } \\
\text { range }\end{array}$ & $\begin{array}{c}70.7 \\
62.5-82.9\end{array}$ & $\begin{array}{c}4.0 \\
1.0-6.1\end{array}$ & $\begin{array}{c}19.7 \\
10.2-25.0\end{array}$ & $\begin{array}{r}2.1 \\
0-3.6\end{array}$ & $\begin{array}{c}2.5 \\
1.9-6.3\end{array}$ & $\begin{array}{c}0.6 \\
0-1.1\end{array}$ & $\begin{array}{c}0.3 \\
0-3.1\end{array}$ & $\begin{array}{c}0.1 \\
0-0.6\end{array}$ & 1062 \\
\hline \multicolumn{4}{|c|}{$\begin{array}{l}\text { Total: Jastarnia, Świbno, Gdańsk } \\
\text { spring, }+1 \text { autumn exp. no } 1\end{array}$} & $\begin{array}{l}\text { average } \\
\text { range }\end{array}$ & $\begin{array}{c}69.6 \\
33.3-100.0\end{array}$ & $\begin{array}{r}5.2 \\
0-33.3\end{array}$ & $\begin{array}{r}17.4 \\
0-32.0\end{array}$ & $\begin{array}{r}2.7 \\
0-5.6\end{array}$ & $\begin{array}{c}3.9 \\
0-33.3\end{array}$ & $\begin{array}{r}0.3 \\
0-2.4\end{array}$ & $\begin{array}{r}0.7 \\
0-7.3\end{array}$ & $\begin{array}{c}0.2 \\
0-0.4\end{array}$ & 2439 \\
\hline Vistula Firth & $22-23$ & 2 & 1 & average & 91.7 & & 8.3 & & & & & & 12 \\
\hline Nieszawa & 24,26 & 2 & 1 & average & 47.6 & 9.5 & 23.8 & 14.3 & & & 4.8 & & 21 \\
\hline $\begin{array}{l}\text { Reda River, Miel- } \\
\text { no, Puck Bay }\end{array}$ & $27-29$ & 3 & $1-2$ & average & 30.8 & 7.7 & 38.4 & 7.7 & 7.7 & 7.7 & & & :13 \\
\hline $\begin{array}{l}\text { Sł'pia River } \\
\text { Wieprza } \\
\text { River }\end{array}$ & $36-39$ & 4 & 1 & average & 73.7 & 5.3 & 21.0 & & & & & & 19 \\
\hline $\begin{array}{l}\text { Grand } \\
\text { Total }\end{array}$ & & 32 & $0+, 1,2$ & $\begin{array}{l}\text { average } \\
\text { range }\end{array}$ & $\begin{array}{c}69.4 \\
30.8-100.0\end{array}$ & $\begin{array}{c}5.2 \\
0-33.3\end{array}$ & $\begin{array}{c}17.5 \\
0-38.5\end{array}$ & $\begin{array}{c}2.8 \\
0-13.6\end{array}$ & $\begin{array}{c}3.9 \\
0-33.3\end{array}$ & $\begin{array}{r}0.3 \\
0-7.7\end{array}$ & $\begin{array}{c}0.7 \\
0-4.5\end{array}$ & $\begin{array}{c}0.2 \\
0-0.4\end{array}$ & 2504 \\
\hline
\end{tabular}




\section{DISCUSSION}

Effectiveness of stocking expressed in $\mathrm{kg}$ of catch per 1000 released fishes determines the final effect of this measure. This effect embraces the impact of different factors and their intensiveness.

These factors can be divided into 3 groups. The first embraces those, the final effect of which consists of the number (per cent) of returned tags. Mention can be made here of the season and place of stocking, age and size of the fishes. Second group of factors is connected with fish growth, and the third - with exploitation.

The effect of these various factors was reflected in the catch of tagged fishes, which ranged between 0.4 and $418 \mathrm{~kg} / 1000$ released specimens (Tab. 1). Similarly as in case of sea trout stocking (Backiel and Bartel 1967, Bartel 1975b), also in this case low values were obtained for autumn releases.

On the other hand, spring stockings were usually successful, with the excpetion of a few experiments only. Place of the release was very significant in this case. Good results were obtained only for the fishes released into the Gulf of Gdańsk and the Vistula mouth. They amounted to $34.2-296.8 \mathrm{~kg}$, at average level of 126.1 and 134.3 for one-year old trout released at Gdańsk and Swibno, and to $155.4-418 \mathrm{~kg}$, at average level of $259.1 \mathrm{~kg}$ for two-years old fishes (Tab. 1). These results are similar to the results obtained for sea trout released at the same sites in 1958-1961 (Backiel and Bartel 1967). On the other hand, much higher levels were obtained for sea trout released in 1965-1968, i.e. 954.3 and $1060 \mathrm{~kg}$ (Bartel 1975b). Similarly high effectiveness was found by Pałka (1977) for sea trout released into the Dunajec River, and by Carlin (1959) and Larsson (1977) for salmon in Swedish waters. The results are based on tag returns, so they obviously must be somehow erratic due to tag losses (Backiel 1964, Saunders and Allen 1967), failing in returning the tags, and inhibition of fish movements and stress due to tag presence, resulting in slower growth (Saunders and Allen 1967).

The effects of stockings depended significantly on the size of released fishes, this being reflected in the number of returns, fish growth and rate of the exploitation. Good results were obtained with trouts over $17 \mathrm{~cm}$ long (Bartel 1985). The effect of the number of caught Vistula sea trout on the effectiveness of stocking was 7 times stronger than the effect of growth rate, and 3 times stronger than the effect of exploitation. The effect of the second factor was twice weaker than of the exploitation (Sych at al. 1978, 1979). The results were most significantly determined by the per cent of tag returns. This was noticeable both for one- and two-years old fishes (Fig. 2). Coefficients of correlation between per cent of tag returns and mass $(\mathrm{kg})$ of the catch were highly significant, amounting to $r_{1}=0.971$ and $r_{2}=0.963$ for one- and two-years old fishes respectively.

Apart from the number of fish caught, the final results depended also on the fish growth. Rate of growth is of considerable significance when comparisons are made between rapidly growing forms (for instance Vistual sea trout) and slowly growing ones (for instance, lake trout). Although tag returns for the Vistula sea trout were very low, while those for lake trout almost twice higher (11.6), the results expressed in $\mathrm{kg}$ for each 
1000 released fishes were almost the same in both cases, amounting to 195.2 and $255.5 \mathrm{~kg}$. This was due to almost twice better growth of the Vistula trout. Average individual weight of the two forms amounted to 3.77 and $2.21 \mathrm{~kg}$ respectively (Backiel and Bartel 1967).

Average fish weight depended also on the rate of exploitation. Lake and sea trout was caught mostly in the second year after the release (Backiel and Bartel 1967, Skrochowska 1969, Pałka 1977), whereas rainbow trout was caught a year earlier, in the first and second year after the release. In these two years 43.6 and $88.4 \%$ of one-year old fishes were caught, and 73.3 and $95.7 \%$ of two-year old ones respectively (Tab. 2). Hence, most rainbow trout, especially those released at the age of two years, were caught when they were still fairly small. As a result, average fish weight in 13 experiments (1.6 kg, Tab. 2) was lower than for lake trout $(2.21 \mathrm{~kg})$, although growth rate of the latter was slower than of rainbow trout (Bartel 1985 in print). It should be remembered that per cent of tags returned in the first year after the release correlated significantly with average weight of older fishes.

Number of the fish caught during the first 3-4 months after the release decreased the effectiveness of stocking. This number was quite high, sometimes exceeding $50 \%$ of total tag returns (Tab. 1). Also Trzebiatowski (1979) obtained most returns during the first 3 months. Assuming that only part of the tags from "younger" fishes were returned, it can be stated that real number of the released fishes was lower than the recorded one.

Profitability of stocking depends also on the level of catches obtained by foreign fishermen. Site of stocking was of considerable importance in this case. As regards rainbow trout released at Jastarnia, only $45.5 \%$ were caught by Polish fishermen, while as regards fishes released at Gdańsk and Swibno - from 67.9 to $77.0 \%$ were caught by Poles (Tab. 3). The latter two levels were similar to Polish sea trout catches, which varied from 72.4 to $86.9 \%$ (Backiel and Bartel 1967, Pałka 1977).

The results of stocking with two-years old sea trout, and with one- and two-years old rainbow trout revealed that the effects (calculated in $\mathrm{kg}$ per 1000 released fishes) were much more favourable in case of the first species. However, the relations change when comparison is made between rainbow trout stocking into the Gulf of Gdańsk and its culture in ponds, river enclosures or cages. Releases of 1000 rainbow trouts of $50-60 \mathrm{~g}$ into the Gulf of Gdansk and the Vistula mouth resulted in the catch of 126.1 and $134.3 \mathrm{~kg}$ respectively, the average weight of the fishes being 1.75 and $1.58 \mathrm{~kg}$. In case of pond culture, at $10 \%$ nortality, $180 \mathrm{~kg}$ can be obtained, the average weight of the fishes being $0.2 \mathrm{~kg}$. Moreover, in case of stocking the costs are limited to the cost of stocking material and the stocking operation, whereas in case of pond culture, or culture in other devices, the costs are much higher and embrace feeds, manipulation, costs of culturing devices etc. Furthermore, quality of the fishes caught in the sea is much higher.

Apart from such factors as availability of feeds and proper quality of water, which limit the culture of both species (sea trout and rainbow trout), attention should also be given to water pollution connected with intensive trout culture in ponds, and especially in cages. Increasing difficulties in the supply of proper feeds for intensive trout culture, and 
their increasing cost, result in the fact that extensive production might become more popular. These relationships are presented in Fig. 4 . In pond culture $76 \mathrm{~kg}$ of rainbow trout, of average weight of $200 \mathrm{~g}$, are obtained from 1000 eggs, at average survival rate of $38 \%$ (Goryczko 1975). Value of this production amounts to $7600 \mathrm{zl}$, and it requires $160 \mathrm{~kg}$ of feeds, the food conversion rate being 2.5 . If the fishes are kept in ponds only for the first year, $12.6 \mathrm{~kg}$ are obtained from the same number of eggs, at survival rate of $48 \%$, the average weight of the fishes being $30 \mathrm{~g}$. According to the numerical model by

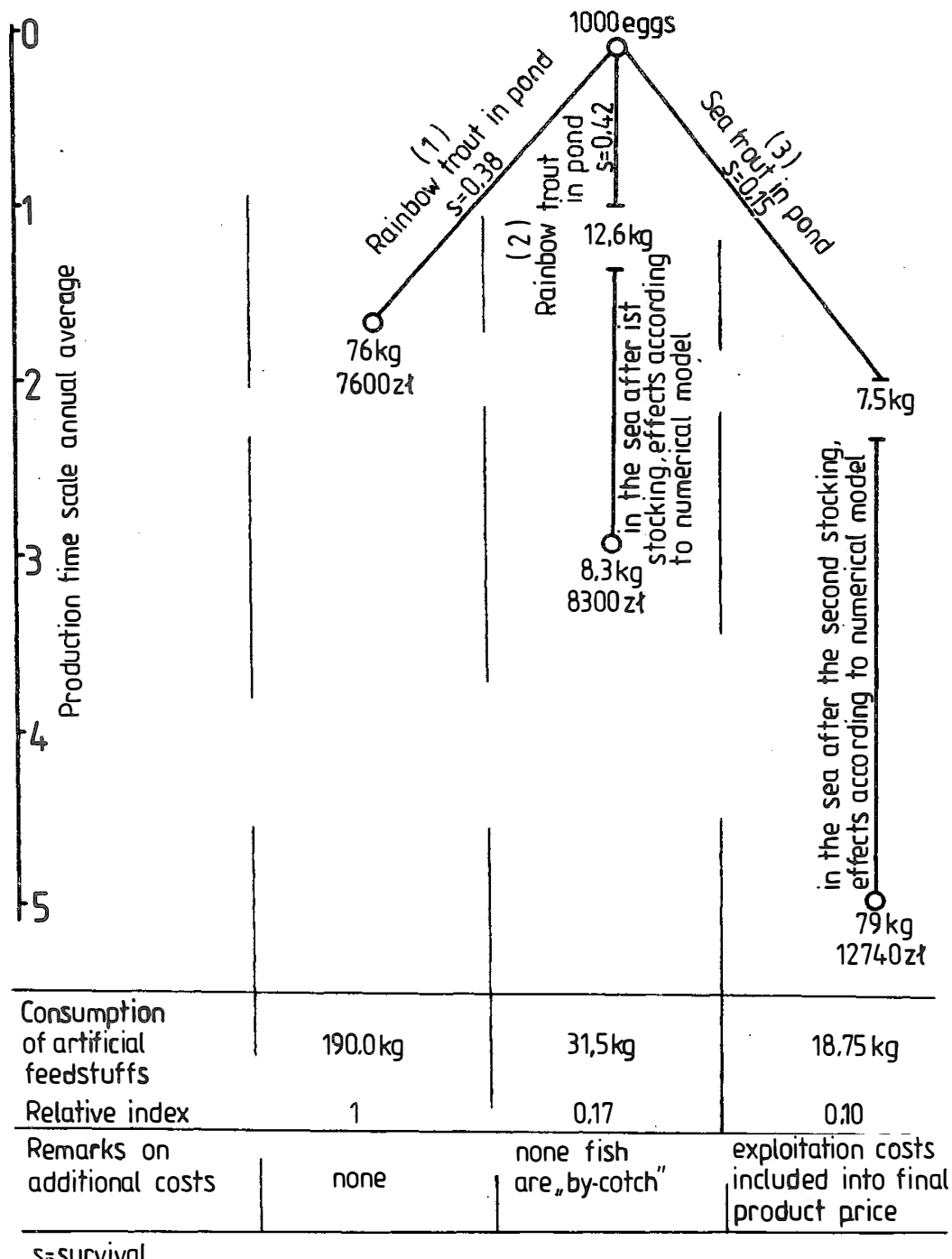

Fig. 4. Comparison of the effects of rainbow trout culture in ponds and stocking into the Baltic Sea of one-year old rainbow trout and two-years old sea trout (according to Sych, personal communication). 
Sych (1972), these fishes stocked into the sea should give $83 \mathrm{~kg}$ of market trout, of the value of $8300 \mathrm{z}$. Only $31.5 \mathrm{~kg}$ of feeds would be used, i.e. $17 \%$ of the amount needed to produce $76 \mathrm{~kg}$ of market trout in ponds. This relative index is even more satisfactory for sea trout. At average survival of $15 \%$, about 150 two-years old smolts should be obtained from 1000 eggs, of average weight amounting to $50 \mathrm{~g}$. Only $18.75 \mathrm{~kg}$ of feeds are used to obtain this production, i.e. $10 \%$ of the level needed to obtain the same production in ponds (Sych 1972).

Calaprice (1976) discussed the use of sea water for fish production and defined it as "sea ranching". This author compared production (catches) from the sea, calculated per 1 ha of area used to produce the stocking material, with the amount of feeds used to obtain this material in relation to the resulting fish catch. This type of calculation results in an estimate of relative breeding area and relative amount of feeds used. As seen in Fig. 5, species for which only hatchery is needed (larvae migrate directly to the sea), such as chum and pink salmon, are most effective. Other species. requiring initial pond

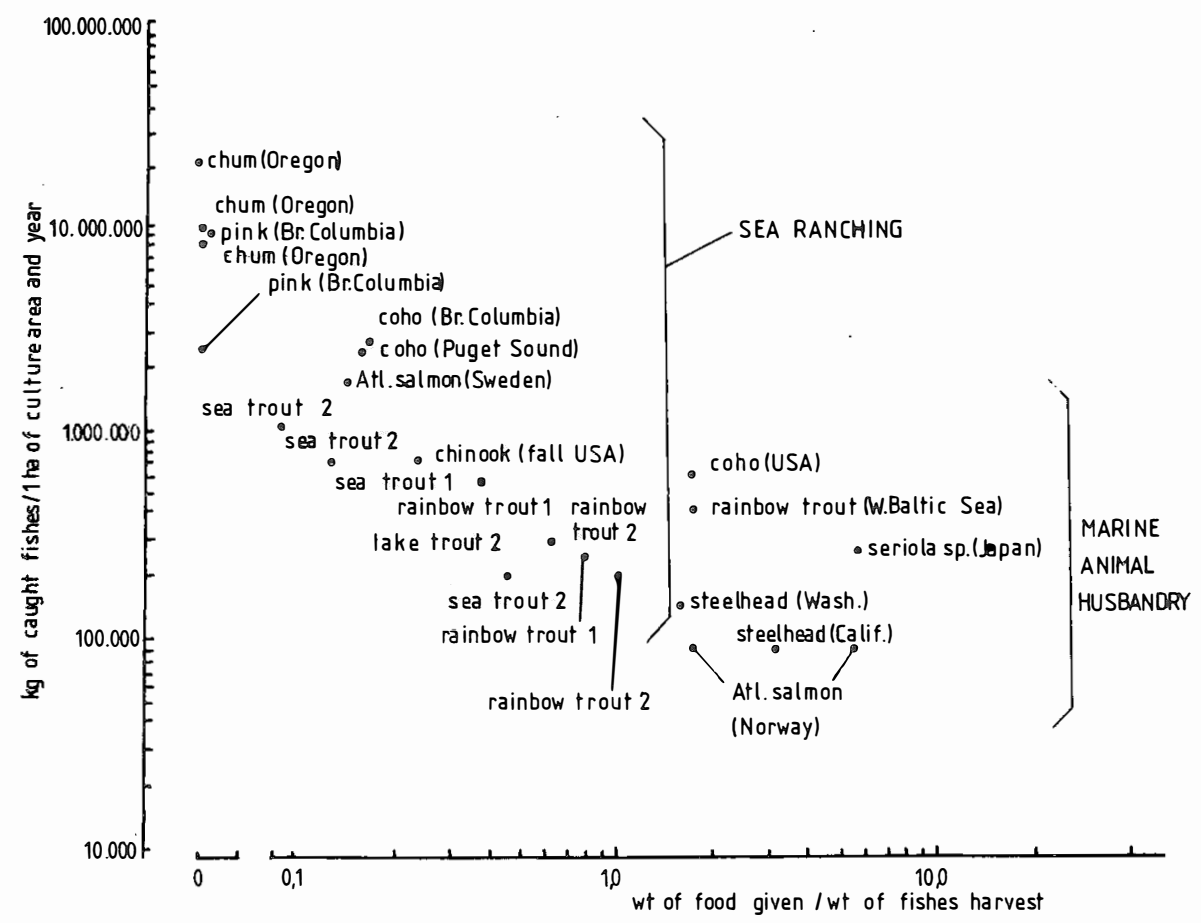

Fig. 5. Condition of stocking and marine culture of salmonids and Seriola $s p$. presented as returns from stockings, or $\mathrm{kg}$ of fish obtained per 1 ha used for the production of stocking material, or else in case of culture - as the relation between wet feeds used and $\mathrm{kg}$ of fish obtained. According to Calaprice (1976), modified and supplemented with own data. Numbers given with the species name represent age of fishes released to the Gulf of Gdańsk and the Vistula mouth. 
Effectiveness of stocking with rainbow and sea trout in

relation to the amount of feed given and pond area used

\begin{tabular}{|c|c|c|c|c|c|c|c|}
\hline Species & $\begin{array}{l}\text { Age of } \\
\text { released } \\
\text { fish }\end{array}$ & $\begin{array}{c}\% \\
\text { of } \\
\text { return }\end{array}$ & $\begin{array}{l}\text { Average } \\
\text { weight } \\
\text { of } \\
\text { caught } \\
\text { fish, kg }\end{array}$ & $\begin{array}{c}\mathrm{kg} \text { of } \\
\text { catch/1000 } \\
\text { fish } \\
\text { released }\end{array}$ & $\begin{array}{c}\text { fish } \\
\text { catch } \\
\mathrm{kg} / \mathrm{ha} *\end{array}$ & $\begin{array}{c}\mathrm{kg} \text { of food } \\
\text { used } / \mathrm{kg} \\
\text { of fish } \\
\text { caught* }\end{array}$ & Source \\
\hline Rainbow trout & 1 & 15.7 & 1.89 & 296.8 & 703068 & 0.42 & maximal effect (tab. 1) \\
\hline Rainbow trout & 1 & 7.2 & 1.75 & 126.1 & 298709 & 0.95 & average effect \\
\hline Rainbow trout & 2 & 20.9 & 2.00 & 418.0 & 370735 & 0.66 & maximal effect \\
\hline Rainbow trout & 2 & 15.7 & 1.65 & 259.1 & 229803 & 1.06 & average effect \\
\hline Sea trout & 2 & 26.0 & 4.08 & 1060.8 & 1287831 & 0.09 & maximal effect (Bartel 1975) \\
\hline Sea trout & 2 & 5.18 & 3.77 & 195.2 & 236977 & 0.5 & Backiel, Bartel (1967) \\
\hline Sea trout & 2 & 21.3 & 2.93 & 624.1 & 757669 & 0.16 & Bartel (1975) \\
\hline Sea trout & 1 & 14.6 & 2.48 & 362.1 & 586112 & 0.28 & Bartel (1975) \\
\hline Lake trout & 2 & 11.6 & 2.21 & 255.5 & 310182 & 0.39 & Backiel, Bartel (1967) \\
\hline
\end{tabular}


breeding and feeding, are much less effective. The lowest effectiveness is noted for species cultured in various devices up to the market size.

Adopting this approach, stocking with two-years old sea trout, made in the Gulf of Gdańsk, was most effective. This resulted from high tag returns and considerable weight of the fishes caught. In other experiments the effects were not so good. Still worse results were obtained with two-years old rainbow trout stocked into the Gulf of Gdańsk, while one-year old trouts gave better effects. In all experiments with rainbow trout considerable amounts of feeds were used, this being connected with high individual weight of the released fishes (Tab. 1, Tab. 4).

The obtained results were based on the informations obtained from tagging experiments. Consequently, they are underestimated due to tag losses, low tag returns, increased frish mortality and their slowe growth, as discussed earlier. All these factors resulted in the fact that the calculated effectiveness was lower than the real one.

It can be stated that the obtained average returns from "older" fishes released into the Gulf of Gdańsk and the Vistula mouth, of 7.2 and $8.5 \%$ respectively, might have been higher, reaching average values of $11-12 \%$. Hence, the results should amount to $190-200 \mathrm{~kg} / 1000$ of released one-year old fishes. Similarly, the results for two-years old fishes should be corrected. However, due to considerable use of feeds during rearing of much bigger fishes, and additional breeding area used for two years, it is recommended not to use two-year old fishes as the stocking material.

Satisfactory results were obtained only in case of fishes released into the Gulf of Gdańsk and the Vistula mouth. Returns from other release sites were low. Also Trzebiatowski (1979) obtained low returns, with considerable percentage of "younger" fishes. This would suggest that the measure was not profitable. Stockings of one-year old rainbow trout into the rivers Słupia and Wieprza in 1978-1980 were also not effective. It can be assumed that direct fish release into the sea would improve the effectiveness of stocking, as the impact of anglers and fishermen during the first weeks after the release would decrease.

The observed differences in rainbow trout migrations, depending on the site of release, suggest a possibility of controlling these migrations and, hence, also fish catches, especially as regards the share of Polish fishermen. The observed concentration of rainbow trout catches in the Gulf of Gdańsk, depending on the release site, suggests that the fishes could be released also in other places (not only at Gdańsk and Swibno) so as to assure the catch.

Adoption of proper strategy of the exploitation might constitute another method of improving the effectiveness of stocking with rainbow trout. It was shown on the basis of a numerical model by Sych (1972) that if the catches were limited in the first year after the release, it would be possible to obtain much better results (Sych and Bartel 1976).

Analysis of rainbow and sea trout stockings into the Gulf of Gdańsk and the Vistula mouth revealed that Vistula sea trout was caught mainly in spring, West Pomerania sea trout in autumn, while rainbow trout in spring and autumn (Sych et al. 1974, 
Bartel 1985b, in print). Hence, introduction of rainbow trout would increase salmonid catches and prolong the season of their exploitation.

Rainbow trout migrated far away from the release sit, and was caught by fishermen from other countries. It appeared that these migrations can be directed by selection of the release site. It would be also advisable do decrease the migrations. Good results were obtained in this respect with coho salmon and chinook salmon when the smolts were kept for some time in cages placed in Puget Sound. These fishes tended to remain in the same water body (Novotny 1975, Joyner 1976). It seems that it would be interesting to keep one-year old trouts in cages for a period of 2-3 months before the release. This might show whether the fishes lost their tendency to migrate, so that catches by Polish fishermen could increase.

In case more intensive stocking with the salmonids were planned in the Baltic Sea, it would be necessary to find out whether food resources were sufficient. It is very difficult to discuss food composition of rainbow trout in the Baltic Sea as the available data are scarce. Mayer (1939) stated that trout released into the Gulf of Wismar fed on herring, Gobidae, Crangon vulgaris. On the other hand Trzebiatowski (1979) stated that rainbow trout fed mainly on fishes, in this on smelt, less frequently on roach, bream, white bream, ruffe and perch, rarely on perch-pike, rudd, crustaceans and insects.

It can be assumed that rainbow trout released into the Gulf of Gdansk would have similar food composition as salmon and sea trout. Some differences might occur due to different distribution of these fishes. Hence, higher percentage of animals inhabiting coastal regions may be expected in the food of rainbow trout.

Moreover, possible differences between food of sea trout, salmon and rainbow trout may be also connected with the fish species. Even fishes inhabiting the same niches had different food composition, as observed by Le Brasseur (1965) for pink salmon, coho salmon, chum salmon, seckeye salmon and rainbow trout.

Chrzan (1979) stated that clupeids constituted $87.5 \%$ of the food of salmon and sea trout in the Baltic Sea. This author determined salmon and trout catches in 1966-1975 at 3074.3 tons. Basing on the food composition and intensity of feeding he concluded that the salmonids used on the average 22.180 tons of food annually, in this 19.970 tons of clupeids. This constitutes only $0.5 \%$ of annual biomass of sprat and herring. According to the ICES Working Group on the Assessment of Pelagic Stocks this biomass amounts to 3961.4 thousand tons (Chrzan 1979). Załachowski (1977) calculated that in southern Baltic cod biomass of 482.044 tons ate 678 thousand tons of clupeids, i.e. $17.1 \%$ of their annual biomass. Totally salmonids and cod ate $17.6 \%$ of the annual biomass of clupeid fishes. Commercial catch of sprat and herring in the Baltic Sea amounted to 614.844 and 559.689 tons in 1977 and 1978 respectively (ICES 1979), i.e. about 15\% of their biomass. Hence, there is still a supply of clupeids which can be used by the salmonids, in this also by the introduced rainbow trout. 


\section{CONCLUSIONS}

1. Average weight of caught rainbow trout varied between 1.07 and $2.35 \mathrm{~kg}$, being the greater the less tagged fishes were caught in the first year after the release.

2. Effectiveness of stocking depended on the returns and average weight of caught fishes. Satisfactory results were obtained only in case of fishes released in spring into the Gulf of Gdańsk and the Vistula mouth, for which higher returns were noted. In this case 126 and $134 \mathrm{~kg}$ were obtained respectively for 1000 released one-year old trouts.

3. Polish fishermen caught $69 \%$ of the tagged trout. Share of fishermen from other countries in rainbow trout catches depended on the fish distribution and migrations.

4. The effectiveness of stocking may be increased by:

- spring release of one-year old trout, the lenght (l. caud.) of the fishes being more than $17 \mathrm{~cm}$,

- selection of the release site, so as to decrease mortality in the first period after the release and assure most satisfactory distribution of "older" fishes,

- limitation of the catches in the first year after the release.

5. Effects of stocking one-year old rainbow trout intn the sea, measured as weight of the catch, were similar as in case of pond culture. However, when consideration was given also to the amount of feeds and breeding area, the results of stocking appeared to be much better than of pond culture. Stocking with two-years old rainbow trout was not effective economically due to longer cycle of fish breeding and - thus - increased costs of production.

\section{REFERENCES}

Backiel T., 1964: Odpadanie znaczków u cert. [Tag losses in Vimba vimba]. Rocz. Nauk Roln. B.84, 2:241-253.

Backiel T., Bartel R., 1967: O efektach zarybiania smoltami troci na tle wyników ich znakowania. [On the effects of stocking with sea trout smolts at the background of tagging results]. Rocz. Nauk Roln. H-90, 3:365-388.

Bartel R., 1973: The results of tagging rainbow trout (Salmo gairdneri Rich.) released in the Baltic Sea. ICES Ana. Cat. Fish. Comm. C.M. 1973/M:10.

Bartel R., 1975a: Znakowanie łososiowatych. [Tagging of the salmonids]. - Gosp. Ryb. 27,7:9-11.

Bartel R., 1975b: Rezultaty zarybienija Baltyki kumzei, czernej i raduznoj foreliami. Referat Rybinprom 1975, Leningrad. (in Russian).

Bartel R., 1985a: Results of stocking of the Baltic Sea with tagged rainbow trout (Salmo gairdneri Rich.) - Acta Ichth. et Pisc. XV, Suppl.: 3-20.

Bartel R., 1985b: Distribution and migrating of tagged rainbow trout (Salmo gairdneri Rich.) released to the Baltic Sea. - Acta Ichth. et Pisc. XV, Suppl.: 21-49.

Bartel R., 1985c: Growth of tagged rainbow trout (Salmo gairdneri Rich.) released to the Baltic Sea. Acta Ichth. et Pisc. XV, Suppl.: 51-63.

Calaprice J.R., 1976: Marikulture - ecological and genetic aspects of production. - J. Fish. Res. Bd. Canada 33,4,2:1068-1087. 
Carlin B., 1959: Results of salmon smolt tagging in the Baltic Sea.- Cons. Perm. Int. Expl. Mer. Charlottenlund Slot. Rap. Proc. Verb. Ren. 147:89-96.

Chrzan F., 1979: Feeding of salmon and sea trout and their food resources in the Baltic Sea.-ICES Ana. Cat. Fish. Comm. C.M. 1979/M:12.

Goryczko K., 1975: Pstragi tęczowe jesiennego tarła - wskazania przy ich chowie. [Autumn spawning rainbow trout - rearing recommendations]. IRS Zakład Upowszechniania Postępu - Olsztyn 92:ss. 13.

ICES, 1979: Report of the Working Group on Assessment of Pelagic Stock in the Baltic Fish. Comm. No 3.

Institut für Kusten und Binnenfischerei, Hamburg, 1970: Regenbogenferellen in Meer. - Informat. Fischwirt. 17/5).

Joyner T., 1976: Farming ocean ranges for salmon. - J. Fish. Res. Bd. Canada 33,4,2:902-904.

Kulmiatycki W.J., 1940: Über das Wachstum und die Wanderungen in der Ostsee ausgesetzten Forelen. - Verh. int. Verein. theor. angew. Limnol., 9:267-275.

Larsson P.O., 1977: The importance of time and place of release of salmon and sea trout on the results of stockings.-ICES Ana. Cat. Fish. Comm. C.M. 1977/M:42.

Le Brasseur R.J., 1965: Stomach contents of salmon and steelhead trout in the Northeastern Pacific Ocean. - J. Fish. Res. Bd. Canada 23,1:85-100.

Meyer P.F., 1939: Aussetzungen von Regenbogenforellen (Salmo irideus Gibb.) in die Ostsee Ber. Deut. Wiss. Komm. Meeresforsch. N.F. IX,2:318-323.

Novotny A.J., 1975: Net-pen culture of Pacific salmon in marine waters.-Mar. Fish. Res. 37,1:36-47.

Pałka W., 1977: Badania nad wędrówkami i powrotem do rzek troci dunajeckiej (Salmo trutta L.). [Studies on the migrations and homing of Dunajec sea trout (Salmo trutta L.)]. Rozprawa doktorska. Akad. Rol. Kraków [dissertation]: s. 44 tab. 16, fig. 4, map. 47.

Saunders R.L., and Allen K.R., 1967: Effects of tagging and of finclipping on the survival and growth of Atlantic salmon between smolt and adult stages. - J.Fish. Res. Bd. Canada 24,12:2595-2611.

Skrochowska S., 1969: Migrations of the sea-trout (Salmo trutta L.), brown trout (Salmon trutta m.fario L.) and their crosses.-Pol. Arch. Hydrobiol. 16,29,2:125-192.

Sych R., 1972: A numerical model of the commercial exploitation of fish. -ICES Ana. Cat. Fish. Comm. C.M. 1972/M:9.

Sych R., Bartel R., 1976: Some examples of locking for improvement of sea trout and rainbow trout exploitation, -ICES Ana. Cat. Fish. Comm. C.M. 1976/M:7.

Sych R., Bartel R. and Majkowski J., 1974: Results of stocking the Baltic Sea with various Salmo trutta populations and Salmo gairdneri as shown by a numerical model. -ICES Ana. Cat. Fish. Comm. C.M. 1974/M:11.

Sych R., Kania J., Przeździecki M., 1980: Współzależność niektórych wymiarów ciała pstrąga tęczowego chowanego w Polsce. [Relationships between some body parameters in rainbow trout bred in Poland]. IRS, Zakład Upowszechniania Postępu Olsztyn: ss. 5, fig. 1.

Sych R., Pałka W., Bieniarz K., 1978: Smolt - size dependent effects of fishing on example of the Vistula sea trout. -ICES Ana. Cat. Fish. Comm. C.M. 1978/M:3.

Sych R., Pałka W., Bieniarz K., 1979: Niektóre następstwa ludzkich ingerencji w skład wielkościowy młodych ryb - na przykładzie troci, Salmo trutta m.trutta L. [Some consequences of human intervention into the size composition of young fishes on the example of sea trout, Salmo trutta m.trutta L.]. Referat. - Third Europ. Ichthyol. Congress Warszawa 18-25 September 1979.

Trzebiatowski R., 1979: Teoretyczne i praktyczne przesłanki możliwości wsiedlania pstrąga tęczowego (Salmo gairdneri Rich.) do wód przymorskich i przybrzeżnych Bałtyku. [Theoretical and practical premises for the introduction of rainbow trout (Salmo gairdneri Rich.) into the coastal waters of the Baltic Sea]. Akad. Rol. Szczecin, Rozprawy No 61:ss. 102. 
Załachowski W., 1977: Ilościowa i ekologiczna analiza pokarmu użytkowanego przez populacje dorsza w południowym Bałtyku w latach 1972-1974. [Quantitative and ecologic analysis of the food composition in cod populations in southern Baltic in 1972-1974]. Akad. Rol. Szczecin. Rozprawy No 53:ss. 109.

Translated: Dr. M. Bnińska

Ryszard Bartel

\section{EFEKTYWNOŚĆ ZARYBIANIA BAŁTYKU PSTRĄGAMI TĘCZOWYMI (SALMO GAIRDNERI RICH.)}

\section{STRESZCZENIE}

W latach 1963-1980 jesienią i wiosną wypuszczono do Zatoki Gdańskiej,Wisły, Redy, Słupi, Wieprzy, Zalewu Wiślanego, Zatoki Puckiej i Bałtyku 40.505 poznakowanych pstragów tęczowych o wielkościach 11-49 $\mathrm{cm}$ w wieku 0+, 1 i 2 lata. $Z$ wypuszczonych ryb otrzymano od 0-14,7\% zwrotów z ryb złowionych w ciągu 3-4 miesięcy po zarybieniu i 0,1 do $20,9 \%$ z pstrągów łowionych po tym okresie. Efektywność zarybiania liczono ilością kilogramów ryb odłowionych w przeliczeniu na 1 tys. wypuszczonych osobników i wahała się ona od 0,4 do $418 \mathrm{~kg}$. Była ona silnie dodatnio skorelowana $\mathrm{z}$ procentem zwrotów a więc także uzależnione od pory roku i miejsca zarybiania. $\mathrm{Z}$ dwurocznych ryb osiagnięto większe ilości kilogramów niż $\mathrm{z}$ jednorocznych ale stosunek masy odłowionych ryb do masy wypuszczonych był podobny u obu grup wiekowych. Zadawalające. rezultaty osiagnięto jedynie przy zarybianiu Zatoki Gdańskiej i ujścia Wisły. Średni ciężar łowionych pstrągów był ujemnie skorelowany z procentem odłowionych ryb „starszych" $\mathrm{w}$ ciągu pierwszego roku $(r=-0,714)$. Wskazuje to na możliwość polepszenia efektów zarybiania przez ograniczenie połowów w tym okresie.

Wykazano wyższą efektywność zarybiania jednorocznymi pstrągami niż efektywność chowu w stawach a niższą $\mathrm{w}$ porównaniu $\mathrm{z}$ rezultatami zarybień trocią wiślaną. Podobnie, porównanie między odłowami ryb a masą skarmionej paszy zużytej dla wyprodukowania materiału zarybieniowego wykazało wyższą bądź równą efektywność zarybień trocią niż pstrągami.

Biorąc pod uwagę biomasę śledzi i szprotów w Bałtyku, wyżeranie ich przez ryby drapieżne (łososiowate $\mathrm{i}$ dorsze) oraz ich połowy można sądzić, że istnieje jeszcze pewna rezerwa bazy pokarmowej, dla wsiedlanych pstrągów tęczowych.

W połowach znakowanych pstragów największy udział mieli rybacy polscy, średnio $69,2 \%$. Wahał się on od 30,8 do $100 \%$ i zależał głównie od miejsca zarybienia.

Wśród rybaków $\mathrm{z}$ innych państw najwięcej pstragów pozyskali rybacy duńscy. 
Р. Бартэль

ЭШФЕКТИВНОСТЬ ЗАРЫБЛЕНИЯ БАЛТИКИ РАДУЖНОЙ ФOPEJbIO (SALMO GAIRDNURI RICH•)

\section{Рез́ме}

В период с 1963 по 1980 гг. осеньо и весной в Гданьскии залив Вислу, Реду, Слупю и Вепш, В Вислинский залив, Пуцкй залив и Балтинское море было выпудено 40505 особей меченой радужной фороли, размером 11-49 см, 0+, 1 и 2 годовников. Из выпущенных рыб получено от О до $14,7 \%$ "возвратов" из рыб, выловленных 3-4 месяца спустя после зарыбления и $0, \perp$ до $20,9 \%$ из форелей, выловленных позднее этого периода. Эуективность зарыбления считали количеством кг рыб, отловленных в пересчёте на 1 тыс. выпущенных особей, іл эта эбобективность колебалась от 0,4 до 418 кг. Наблюдалась чёткал положительная корреляция с процентомивозвратов", то есть также зависела от времени года и места зарыбления. От двугодовиков получили больmее количество кГ, чем от одногодовников, но отношение массы отловленных рыб $к$ отнотению массы выпупенных рыб было подобным в обеих возрастных группах. Удовлетворительных результатов достигали только при зарыблении Гданьского залива и устья Вислы. Среднии вес выловленных ц̌орелей имел отрицательную корреляцию с процентом отловленных "старших" рыб в течение первого года $(r=-0,714)$. 
Всё показывает на возможность увеличения эф̆ектов зарьбления путём ограничения уловов в этот период. Наблюдалась более высокая э.্人ুективность зарыбления форолями годовиками, чем эффективность разведения в прудах, однако она была меньше эйективности зарыбления вислинской кумжей. Также, сравнение между отловами рыб и массой данной рыбам пищи, использованной для получения материала зарыбления, показало выспую или равную э бективность ность зарыбления кумжей, чем юорелью.

Принимая во внимание биомассу сельдей и ппрот в Балтике, пожерание их хищными рыбами (лососевыми и тресковыми), а также их промысел, можно судить, что существует ещё какой-то резерв кормовон базы для заселяемой радужной борели.

В выловах меченой рели самое больпое участие принимали польские рыбаки, в среднем 69,2\%. Оно колебалось от 30,8 до $100 \%$ и зависело от места зарыбления .

Среди рыбаков других стран большее число q:орелей выловили датские рыбаки.

Перевод: К.т.н. Мариуші Лучак

Author's address:

Received: 1984.11.13.

Doc. dr Ryszard BARTEL

Inst. Rybactwa Śódlądowego

Pracownia Rybactwa Rzecznego

Gdynia-Oliwa 80-328

ul. Bytowska 5

Polska (Poland) 